the Ständiger Arbeitsausschuss für die Tagungen der Nobelpreisträger, Lindau im Bodensee, Postfach 11.

\section{United States National Science Foundation : Senior} Postdoctoral Fellowships

Applications are invited by the United States National Science Foundation for a second group of senior postdoctoral fellowships to be awarded during the current calendar year. Fellowships will be awarded in mathematical, physical, medical, biological, engineering and other sciences, including anthropology, psychology (other than clinical), geography, certain interdisciplinary fields, and areas of convergence between the natural and social sciences. To be eligible for these awards, candidates must be citizens of the United States with special aptitude for advanced training and must hold the doctoral degree or have the equivalent in training or experience. Annual stipends to a maximum of 10,000 dollars, adjusted to match as closely as feasible the regular salaries of the recipients, may be applied toward study or research in an accredited non-profit institution of higher learning in the United States or abroad. A limited allowance to aid in defraying costs of travel for a Fellow and his dependants will also be available. Applications and further details can be obtained from the Division of Scientific Personnel and Education, National Science Foundation, Washington 25, D.C.

\section{Zoological Society of India}

The new Executive Council of the Zoological Society of India has been elected as follows: President, Dr. M. L. Roonwal, director, Zoological Survey of India, Calcutta ; Vice-Presidents, Dr. H. S. Rao, Katpadi, and Dr. G. S. Thapar, Lucknow ; Editor, Prof. R. V. Seshaiya, Annamalai University, Annamalainagar ; Secretary, Prof. P. N. Ganapati, Andhra University, Waltair ; Treasurer, Dr. B. S. Chauhan, Zoological Survey of India, Calcutta; Manager of Publications, Shri K. Chidambaram, New Delhi; Members, Dr. N. K. Panikkar and Dr. B. N. Chopra, New Delhi; Dr. B. Prashad, Dehra Dun; Dr. M. A. Moghe, Poona; Dr. J. L. Bhaduri and Dr. H. N. Ray, Calcutta.

\section{Royal Aeronautical Society: Officers}

THe following have been appointed officers of the Royal Aeronautical Society for 1957-58 : President, Sir George Edwards; Past Presidents, E. T. Jones, N. E. Rowe, Sir Sydney Camm; President-elect, Sir Arnold A. Hall; Vice-Presidents, P. G. Masefield, Dr. E. S. Moult, Air Marshal Sir Owen Jones; Honorary Treasurer, Major G. P. Bulman ; Secretary, Dr. A. M. Ballantyne.

\section{University News :}

London

THe following appointments in the University of London are announced: Dr. R. A. Buckingham, reader in physics at University College, to the post of director of the University of London Computational Unit ; Dr. R. S. Scorer, lecturer in the Department of Meteorology at the Imperial College of Science and Technology, to the University readership in applied mathematies tenable at that College.

Malaya

Prof. T. F. Dixon, of the Department of Biochemistry, Royal Faculty of Medicine, Baghdad, has been appointed professor of biochemistry in the
University of Malaya, in succession to Prof. J. W. H. Lugg, who has gone to the University of Western Australia. Prof. Dixon hopes to be in Britain during July and August, when his address will be c/o The Royal Society of Medicine, 1 Wimpole Street, London, W.1.

\section{Announcements}

Sir Edward Appleton opened the new Radio Research Station near Slough of the Department of Scientific and Industrial Research on June 20.

Sir Harold Roxbet Cox, a director of Wilmot Breodon (Holdings), Ltd., and of the Brush Group, Ltd., formerly chief scientist to the Ministry of Fuel and Power, and Dr. C. J. Smithells, managing director of Magnesium Elektron, Ltd., and a former director of research to the British Aluminium Co., Ltd., have been appointed members of the Council for Scientifie and Industrial Research.

Prof. Robert Millner Shackleton, Jane Herdman professor of geology in the University of Liverpool, has been awarded the Liverpool Geological Society Medal for 1956-57.

Dr. J. M. Rowson, curator of the Museum of the Pharmaceutical Society of Great Britain, has been appointed head of the Department of Pharmacy in the Nigerian College of Arts, Science and Technology.

THE ninth meeting of the International Whaling Commission is to be held at 10 Carlton House Terrace, London, S.W.1, during the week beginning Monday, June 24.

THE twenty-fifth anniversary of the International 'Tin Research Council is to be marked by two open days, on July 10 and 11, at the Council's head. quarters and laboratories, at the Tin Research Institute, Fraser Road, Greenford, Middlesex.

Tне 1957 Electronics Exhibition and Convention, organized by the Northern Division of the Institution of Electronics, will be held at the College of Technology, Manchester, during July 11-17. Tickets for the Exhibition, which includes Manufacturers and Scientific and Industrial Research Sections, can be obtained from exhibitors or from the honorary exhibition organizer, Mr. W. Birtwistle, 78 Shaw Road, Rochdale, Lancashire.

A LECTURE organized by the Institution of Electronies will be held at 6 p.m. on July 5 in the Beveridge Hall of the Senate House, University of London. It will take the form of a joint lecture, illustrated by sound film and slides, on "The Theoretical Problems of Television Astronomy", by Dr. P. B. Fellgett, and on "The 1956 Opposition of Mars", by B. V. Somes-Charlton. The meeting is open to members and friends, and non-members are also invited. Admission tickets are available from the hon. general secretary, Mr. W. Birtwistle, 78 Shaw Road, Rochdale, Lancashire, or from Mr. C. H. Messenger, 38 Hainault Court, Forest Rise, London, E.17.

WE regret that in the article on the annual congress of the South-eastern Union of Scientific Societies published in Nature of June 15, p. 1231, Major Maxwell Knight has been confused with Capt. C. W. R. Knight, author and lecturer on bird life, who died on May 19. 